\title{
Trichomycterus venulosus (Steindachner, 1915), a junior synonym of Eremophilus mutisii Humboldt, 1805 (Siluriformes: Trichomycteridae) and not an extinct species
}

\author{
Carlos DoNascimiento ${ }^{1}$, Saúl Prada-Pedreros² and Jürgen Guerrero-Kommritz ${ }^{3}$
}

\begin{abstract}
Reexamination of the syntypes of the enigmatic Trichomycterus venulosus, described from Páramo de Cruz Verde, Eastern Cordillera of Colombia, allowed us to assess its actual taxonomic status. This nominal species is demonstrated to constitute a junior synonym of Eremophilus mutisii, and then not represents a case of extinction of a fish endemic to Colombia, as currently accepted.

O reexame dos síntipos do enigmático Trichomycterus venulosus, descrito do Páramo de Cruz Verde, Cordilheira Oriental da Colômbia, nos permitiram avaliar o seu status taxonômico atual. Demonstra-se que esta espécie nominal constitui um sinônimo júnior de Eremophilus mutisii, e, portanto, não representa um caso de extinção de um peixe endêmico da Colômbia, como atualmente é aceito.
\end{abstract}

Key words: Catfish, Páramo de Cruz Verde, Pelvic-less, Taxonomy, Trichomycterinae.

\section{Introduction}

Trichomycterus venulosus was described by Steindachner (1915a), from Páramo de Cruz Verde, in the Eastern Cordillera of Colombia. This species is known from only two syntypes housed at Naturhistorisches Museum Wien (NMW), and additional material has not been subsequently referred in the literature. For that reason, an assessment project to evaluate the conservation status of this species was conducted between 2004 and 2005, at its type locality (Prada-Pedreros et al., 2006). A series of collections were made in the Páramo de Cruz Verde, both in the flank draining to the río Magdalena and the flank draining to the río Orinoco basin, all of which failed in the capture of any specimen of $T$. venulosus, although resulted in the collection of a very different Trichomycterus species which is being described in another contribution. Hence, a reexamination of the syntypes of $T$. venulosus was carried out, incorporating novel information derived from the skeleton through $\mathrm{x}$-ray images, in order to verify the taxonomic status of this nominal species.

\section{Material and Methods}

Nomenclature of sensory pores of supraorbital and infraorbital canals followed Arratia \& Huaquin (1995). Osteological preparations (indicated as CS) followed the method of Taylor \& Van Dyke (1985). Vertebral counts included only free vertebrae (posterior to Weberian complex), and the compound caudal centrum (PU1+U1) was counted as one element (Lundberg \& Baskin, 1969). Institutional abbreviations follow Ferraris (2007), with the inclusion of CZUT-IC, Colección Zoológica Universidad del Tolima, Ictiología, Ibagué, Colombia; IAvH-P, Colección de Peces Dulceacuícolas, Instituto Alexander von Humboldt, Villa de Leyva, Colombia; IMCN, Colección Zoológica de Referencia del Museo de Ciencias Naturales Federico Carlos Lehmann Valencia del INCIVA, Cali, Colombia; MBUCV-CT, Colección de Transparencias de Peces del Museo de Biología de la Universidad Central de Venezuela, Caracas, Venezuela; MPUJ, Museo Javeriano de Historia Natural "Lorenzo Uribe S. J.", Bogotá, Colombia. Other abbreviations: RX, radiograph; SL, standard length.

\footnotetext{
${ }^{1}$ Departamento de Biología / Museo de Zoología de la Universidad de Carabobo, Facultad Experimental de Ciencias y Tecnología, Universidad de Carabobo, Valencia 2005, Venezuela. cdonascimiento@uc.edu.ve

${ }^{2}$ Unidad de Ecología y Sistemática, Departamento de Biología, Pontificia Universidad Javeriana, Cra. 7 No. 40-82, Bogotá, Colombia. saul.prada@javeriana.edu.co

${ }^{3}$ Fundación para el Desarrollo de la Biología Aplicada (Fundabas), Calle 92 No. 13-68, Apto. 401, Bogotá, Colombia. greledone@ hotmail.com
} 


\section{Results}

The first character that calls our attention upon the morphological distinctiveness of the syntypes of Trichomycterus venulosus is the consistent absence of pelvic fins. This external pelvic-less condition is also accompanied by the corresponding lack of the basypterigia internally, as revealed by radiographs. Steindachner (1915b) was certainly aware about this remarkable feature of his new species, given that the illustration provided in that work is unequivocal on the absence of pelvic fins (Fig. 1A), besides two other species of Trichomycterus (T. fassli and T. transandianus) were also described in that same work, and meristic and morphometric data of the pelvic fin are presented in their respective descriptions and corresponding tables, which was not the case for T. venulosus. However, absence of pelvic fins is not exclusive to this species, having homoplastic distribution within trichomycterids (de Pinna, 1989; Fernández \& Vari,
2000). At least three species of Trichomycterus Valenciennes, 1832 also lack both pelvic fin and girdle: T. candidus (Miranda Ribeiro, 1949), formerly described in Eremophilus and later relocated in Trichomycterus, according to morphological evidence supporting its closer relationships to a clade of Trichomycterus species from southeastern Brazil (Barbosa \& Costa, 2003); T. catamarcensis Fernández \& Vari, 2000 from Argentinean Andes; and T. tropeiro Ferrer \& Malabarba, 2011 from southern Brazil. Other trichomycterines lacking pelvic fins are Eremophilus mutisii Humboldt, 1805, at present the single species in that genus which was originally defined by its pelvic-less condition, and three recently described species of Silvinichthys: S. bortayro Fernández \& de Pinna, 2005, S. leoncitensis Fernández, Dominino, Brancolini \& Baigún, 2011, and S. gualcamayo Fernández, Sanabria \& Quiroga, 2013, which together seem to conform a monophyletic group within that genus (Fernández et al., 2013).
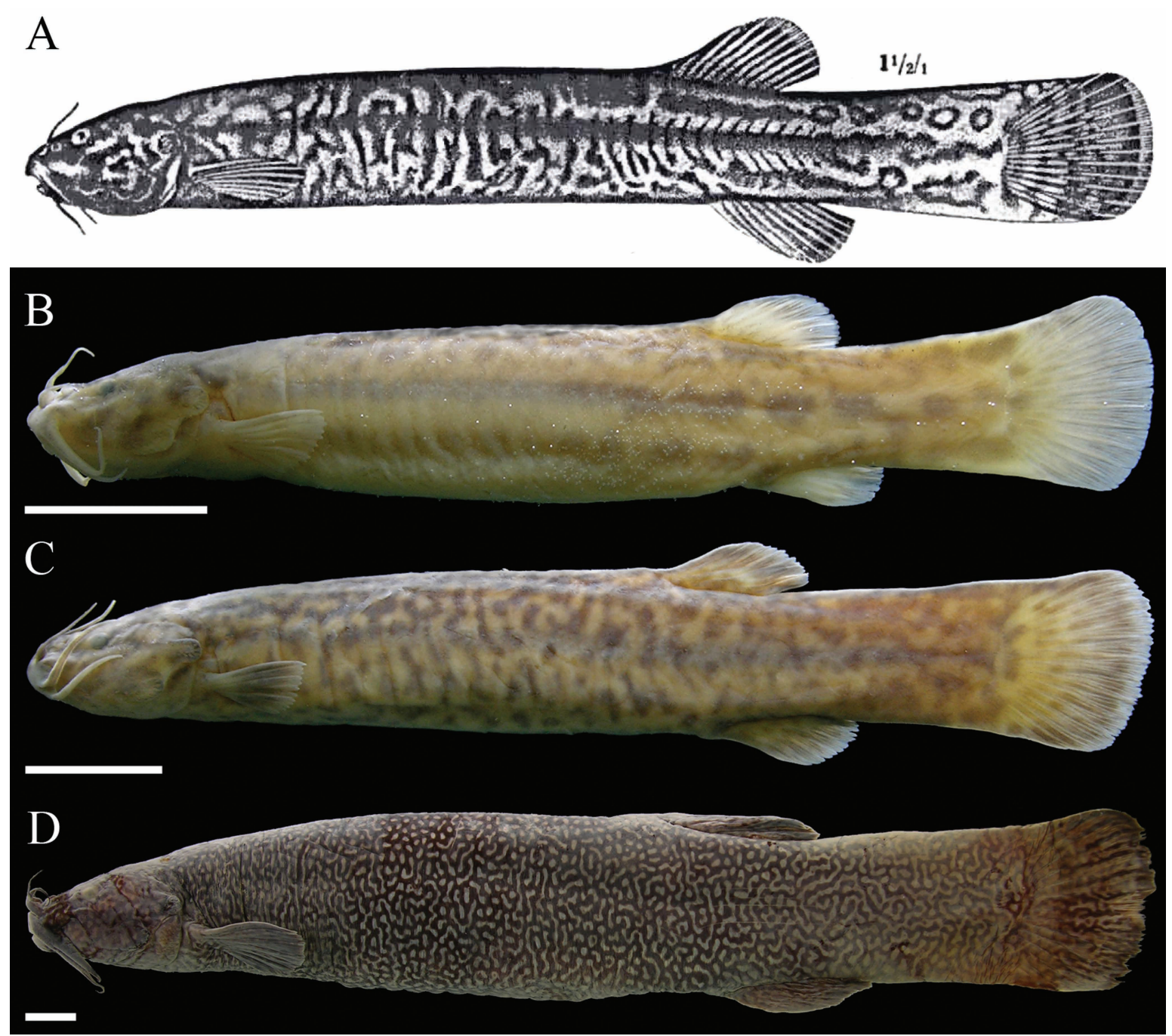

Fig. 1. A. Trichomycterus venulosus, syntype of Pygidium venulosum, $87 \mathrm{~mm}$ SL, illustration from Steindachner (1915b); B. Eremophilus mutisii, MPUJ 2528, $54.0 \mathrm{~mm}$ SL, Colombia, Cundinamarca, Municipio Guatavita, embalse de Tominé, Vereda Chaleche, Club Náutico Refugio de Tominé, 459'10.7'N 7349'09'W, $2622 \mathrm{~m}$ asl, río Magdalena basin; C. E. mutisii, MPUJ 2528, 72.1 mm SL; D. E. mutisii, MBUCV-V-32796, 221.9 mm SL, Colombia, Nariño, Laguna de La Cocha, río Guamuéz drainage, tributary of río Putumayo, Amazon River basin. Scale bars $1 \mathrm{~cm}$. 
A second external character uncommon in the context of the documented morphological variation of Trichomycterus is the presence of three pairs of supraorbital sensory pores on dorsal surface of snout region in both syntypes of Trichomycterus venulosus (Fig. 2). The two anterior most sensory pores are placed medially adjacent to anterior and posterior nares respectively, while last pair is located a little in advance to anterior margin of eyes. The three supraorbital sensory pores are longitudinally aligned medial to inner margin of eye. According to their topographical placement these sensory pores correspond in anteroposterior order to pores $\mathrm{s} 1, \mathrm{~s} 2$, and $\mathrm{s} 3$. This arrangement pattern of supraorbital sensory pores is typically found in species of trichomycterids that have the nasal section of the supraorbital canal interrupted from the frontal section, thus giving origin to an extra pair of pores (s2). Accordingly presence of sensory pores $\mathrm{s} 2$ in syntypes of $T$. venulosus suggests a similar interruption of the supraorbital canal. This pattern was verified in all examined specimens of Eremophilus mutisii, and has been recorded for T. punctulatus Valenciennes, 1846 and T. rivulatus Valenciennes, 1846 by Arratia (1998), and for $T$. aguarague Fernández \& Osinaga, 2006, T. alterus (Marini, Nichols \& La Monte, 1933), T. areolatus Valenciennes, 1846, T. belensis Fernández \& Vari, 2002, T. chiltoni (Eigenmann, 1920), T. chungaraensis Arratia, 1983, T. dispar (Tschudi, 1846), T. heterodontus (Eigenmann, 1918), T. laucaensis Arratia, 1983, T. ramosus Fernández, 2000, and T. vittatus Regan, 1903 by Fernández (2006), as well as for the recently described T. megantoni Fernández \& Quispe Chuquihuamaní, 2007, and T. minus Fernández \& Vari, 2012, in their respective original descriptions. All of these species also have in common an Andean restricted distribution. A continuous supraorbital canal with only two sensory pores (s1 and s3) on snout region, and corresponding lack of supraorbital sensory pore s2 is a more widespread condition in Trichomycterus as verified in T. alternatus (Eigenmann, 1918), T. arleoi (FernándezYépez, 1972), T. banneaui (Eigenmann, 1912), T. barbouri (Eigenmann, 1911), T. bogotensis (Eigenmann, 1912), T. brasiliensis Reinhardt, 1874, T. cachiraensis Ardila Rodríguez, 2008, T. caliensis (Eigenmann, 1912), T. celsae Lasso \& Provenzano, 2003, T. chapmani (Eigenmann, 1912), T. conradi (Eigenmann, 1912), T. davisi (Haseman, 1911), T. dorsostriatus (Eigenmann, 1918), T. етапиeli (Schultz, 1944), T. gorgona Fernández \& Schaefer, 2005, T. guianensis (Eigenmann, 1909), T. iheringi (Eigenmann, 1918), T. immaculatus (Eigenmann \& Eigenmann, 1889), T. knerii Steindachner, 1882, T. latistriatus (Eigenmann, 1918), T. lewi Lasso \& Provenzano, 2003, T. maracaiboensis (Schultz, 1944), T. meridae Regan, 1903, T. mondolfi (Schultz, 1945), T. motatanensis (Schultz, 1944), T. ocanaensis Ardila Rodríguez, 2012, T. oroyae Eigenmann \& Eigenmann, 1889, T. paolencis (Eigenmann, 1918), T. pardus Cope, 1874, T. piurae (Eigenmann, 1922), T. pradensis Sarmento-Soares, Martins-Pinheiro, Aranda \& Chamon, 2005, T. reindhardti (Eigenmann, 1918), T. retropinnis Regan, 1903, T. romeroi (Fowler, 1941), T. ruitoquensis Ardila Rodríguez 2007, T. santaeritae (Eigenmann, 1918), T. sketi Castellanos-Morales, 2011, T. spelaeus DoNascimiento, Villarreal \& Provenzano,
2001, T. stellatus (Eigenmann, 1918), T. striatus (Meek \& Hildebrand, 1913), T. taeniops Fowler, 1954, T. transandianus (Steindachner, 1915), T. triguttatus (Eigenmann, 1918), T. uisae Castellanos-Morales, 2008, T. vermiculatus (Eigenmann, 1918), T. weirauchi (Fowler, 1945), and T. zonatus (Eigenmann, 1918), having been also recorded in T. nigricans Valenciennes, 1832 by Arratia (1998), T. candidus, T. mimonha Costa, 1992, and T. mirissumba, Costa, 1992 by Barbosa \& Costa (2003) and in most of the recently described species: T. potschi Barbosa \& Costa, 2003; T. trefauti Wosiacki, 2004; T. caudofasciatus and T. pantherinus Alencar \& Costa, 2004; T. maracaya Bockmann \& Sazima, 2004; T. jacupiranga and T. tupinamba Wosiacki \& Oyakawa, 2005; T. guaraquessaba Wosiacki, 2005; T. pauciradiatus Alencar \& Costa, 2006; T. therma Fernández \& Miranda, 2007; T. igobi and T. crassicaudatus Wosiacki \& de Pinna, 2008; T. hualco Fernández \& Vari, 2009; T. brunoi, T. claudiae, T. fuliginosus, T. macrotrichopterus, T. mariamole, T. novalimensis, T. rubiginosus, and T. maculosus Barbosa \& Costa, 2010; T. tropeiro Ferrer \& Malabarba, 2011; T. tete Barbosa \& Costa, 2011; T. payaya Sarmento-Soares, Zanata \& Martins-Pinheiro, 2011; T. perkos Datovo, Carvalho \& Ferrer, 2012; T. argos Queiroz Lezama, Triques \& Santos 2012; T. pirabitira Barbosa \& Azevedo-Santos, 2012; T. balios, T. brachykechenos, T. diatropoporos, and T. poikilos Ferrer \& Malabarba, 2013; T. piratymbara and T. septemradiatus Katz, Barbosa \& Costa, 2013; T. gasparinii and T. mimosensis Barbosa, 2013. In contrast to those Trichomycterus species having supraorbital sensory pore s2, species lacking such a pore span the entire known geographic distribution of the genus in Central America and cis and trans Andean basins of South America.

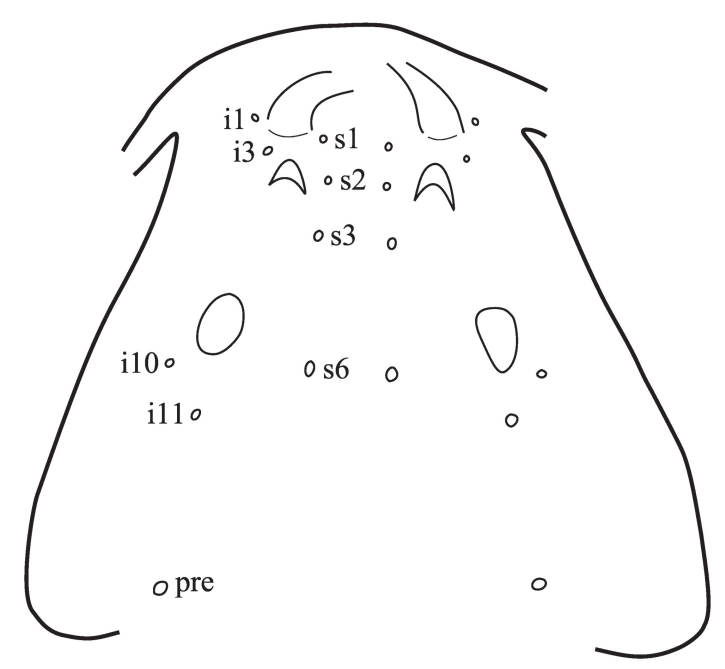

Fig. 2. Dorsal view of head of syntype of Pygidium venulosum (NMW 44476: 1, 108.0 mm SL), showing cephalic sensory pores. Abbreviations: i1, infraorbital sensory pore 1; i3, infraorbital sensory pore 3; i10-11, infraorbital sensory pores 10 and 11; pre, preopercular sensory pore; s1-3, supraorbital sensory pores $1-3$; s6, supraorbital sensory pore 6 (epiphyseal branch). 
The third character found to be informative on taxonomic identity of Trichomycterus venulosus was verified from radiographs and is expressed as a high number of precaudal vertebrae (Table 1). The only other trichomycterines known to have overlapping ranges of precaudal vertebrae to that found in T. venulosus are Eremophilus mutisii (Table 1) and T. tupinamba described from the rio Ribeira de Iguape basin in southeastern Brazil, which has 16-17 vertebrae (Wosiacki \& Oyakawa, 2005). Reported numbers of precaudal vertebrae for Trichomycterus species are generally lower and do not exceed 13 vertebrae: T. boylei (Nichols, 1956) (4-11 vertebrae), and T. duellmani and T. roigi Arratia \& Menu-Marque, 1984 (8-13 and 7-9 vertebrae, respectively) in Arratia \& Menu Marque (1984); T. nigricans (6 vertebrae) in Arratia (1998); T. alterus (5 vertebrae) in Fernández \& Osinaga (2006); and $T$ catamarcensis (8-10 vertebrae); $T$. spelaeus ( 8 vertebrae); T. yuska Fernández \& Schaefer, 2003 (9-11 vertebrae); T. gorgona (7-8 vertebrae); T. aguarague
(5 vertebrae); T. therma ( 8 vertebrae); T. megantoni ( 9 vertebrae); T. caipora Lima, Lazzarotto \& Costa, 2008 (12 vertebrae); T. hualco (9-10 vertebrae); T. payaya (12-13 vertebrae); Trichomycterus minus (7 vertebrae); T. perkos (6-8 vertebrae), according to their respective original descriptions.

The last character that is also peculiar in Trichomycterus venulosus corresponds to its reticulated coloration pattern, which is uncommon for trichomycterids, and agrees in all respects with that of juvenile specimens of Eremophilus mutisii (Figs. 1B, C), which additionally show a dark faint mid-lateral band that fades when the fish becomes larger (Fig. 1D). Fading of this band was already noticed by Steindachner (1915b) for its larger syntype specimen. In fact body size of the two syntypes of $T$. venulosus (87 and $108 \mathrm{~mm} \mathrm{SL}$ ), fall within the range expected for juvenile specimens of $E$. mutisii, whose adults can exceed $500 \mathrm{~mm}$ in SL (Dahl, 1971), being the largest species in the family.

Table 1. Comparative list of osteological and meristic characters for Trichomycterus venulosus (NMW 44476: 1, syntype of Pygidium venulosum), Eremophilus mutisii (MPUJ 1963, 1 CS; MPUJ 1599, 2 RX) and Trichomycterus sp. A (Páramo de Cruz Verde) (MBUCV-CT-1047, 1 CS; MBUCV-CT-1053, 3 CS; MPUJ 2482, 6 RX; MPUJ 2491, 2 RX; MPUJ 4191, 1 RX).

\begin{tabular}{|c|c|c|c|}
\hline Characters & Trichomycterus venulosus & Eremophilus mutisii & $\begin{array}{c}\text { Trichomycterus sp. A (Páramo de Cruz } \\
\text { Verde) }\end{array}$ \\
\hline Premaxilla shape & $\begin{array}{l}\text { Anterior margin extending more } \\
\text { laterally than posterior margin, } \\
\text { forming a conspicuous pointed } \\
\text { lateral projection. Lateral margin } \\
\text { slightly concave }\end{array}$ & $\begin{array}{l}\text { Anterior margin extending more } \\
\text { laterally than posterior margin }\end{array}$ & $\begin{array}{l}\text { Anterior margin not extending more } \\
\text { laterally than posterior margin. Lateral } \\
\text { margin convex. Second and third teeth } \\
\text { rows extending slightly more laterally } \\
\text { than anterior and posterior rows }\end{array}$ \\
\hline Premaxilla relative length & Similar to maxilla & $\begin{array}{l}\text { Premaxilla equal or slightly shorter } \\
\text { than maxilla }\end{array}$ & Longer than maxilla \\
\hline Autopalatine & $\begin{array}{l}\text { Posterolateral process extending } \\
\text { posteriorly to anguloarticular } \\
\text { articulation with quadrate }\end{array}$ & $\begin{array}{l}\text { Posterolateral process extending } \\
\text { posteriorly to anguloarticular } \\
\text { articulation with quadrate. Lateral } \\
\text { margin slightly convex }\end{array}$ & $\begin{array}{l}\text { Posterolateral process forming a } \\
\text { conspicuous angle with the lateral } \\
\text { margin }\end{array}$ \\
\hline Branchiostegal rays & 8 & $7-8$ & $6-7$ \\
\hline Pectoral-fin rays & 8 & 8 & $8-9$ \\
\hline Precaudal vertebrae & 17 & $17-18$ & $9-13$ \\
\hline Caudal vertebrae & 25 & 25 & $27-32$ \\
\hline Ribs & 18 & $16-18$ & $14-18$ \\
\hline First hemal spine & Vertebra 19 & Vertebra 19 & Vertebrae $16-19$ \\
\hline Dorsal-fin rays & 13 & $13-14$ & $11-13$ \\
\hline Dorsal-fin basal radials & 10 & 10 & 8 \\
\hline Dorsal-fin insertion & Vertebrae $21-27$ & Vertebrae $21-27$ & Vertebrae $18-23 ; 18-24 ; 19-24$ \\
\hline Anal-fin rays & 11 & 11 & $11-12$ \\
\hline Anal-fin basal radials & 8 & 8 & $6-7$ \\
\hline Anal-fin insertion & Vertebrae $25-31$ & Vertebrae $25-31$ & Vertebrae $22-26 ; 23-27 ; 23-28 ; 24-28$ \\
\hline $\begin{array}{l}\text { Neural spine of compound caudal } \\
\text { vertebra }\end{array}$ & $\begin{array}{l}\text { Complete, } c a .1 / 3 \text { of adjacent } \\
\text { neural spine height }\end{array}$ & $\begin{array}{l}\text { Complete, } 1 / 3^{-1 / 2} \text { of adjacent } \\
\text { neural spine height }\end{array}$ & $\begin{array}{l}\text { Complete, with a short rounded tip, } \\
\text { and base having conspicuous broad } \\
\text { anterior and posterior apophysis }\end{array}$ \\
\hline Dorsal procurrent caudal-fin rays & 13 & $13-16$ & $16-21$ \\
\hline Dorsal procurrent rays origin & Vertebra 6 & Vertebrae 6-8 & Vertebrae $7-10$ \\
\hline Ventral procurrent caudal-fin rays & 12 & $12-15$ & $14-17$ \\
\hline Ventral procurrent rays origin & Vertebra 6 & Vertebrae 6-8 & Vertebrae $8-10$ \\
\hline Caudal skeleton & $\mathrm{PH}+1+2,3,4+5$ & $\mathrm{PH}+1+2,3,4+5$ & $\mathrm{PH}+1+2,3+4+5$ \\
\hline
\end{tabular}


As seen from the taxonomic distribution of the above commented characters for Trichomycterus venulosus, these features are simultaneously showed only by Eremophilus mutisii, type species of a genus that was traditionally diagnosed by its lack of pelvic fins (Eigenmann, 1918). Furthermore, the larger syntype specimen of $T$. venulosus (108 mm SL) was radiographed, allowing a more comprehensive evaluation of several osteological characters discernible from standard x-ray images. These additional osteological data were compared in available specimens of E. mutisii, which included some topotypes (no types known according to de Pinna \& Wosiacki, 2003 and Ferraris, 2007) and the Trichomycterus species recently collected from Páramo de Cruz Verde, showing complete correspondence with those conditions recorded in E. mutisii, and confirming the different taxonomic identity of Trichomycterus sp. A (Páramo de Cruz Verde) (Table 1). Therefore from the common absence of pelvic fins, shared presence of an apomorphic interrupted nasal section of the supraorbital canal, high number of precaudal vertebrae (17-18), and same coloration pattern, along with all the remaining evidence presented in the Table 1, there is no doubt about the conspecificity of $T$. venulosus with $E$. mutisii, then being the name $T$. venulosus considered as a junior synonym of E. mutisii.

Material examined. NMW 44476, 1, syntype of Pygidium venulosum, $108.0 \mathrm{~mm}$ SL; NMW 44476, 1, syntype of Pygidium venulosum, $87.0 \mathrm{~mm}$ SL, Páramo de Cruz Verde, Eastern Cordillera, $3000 \mathrm{~m}$ a.s.l.

\section{Discussion}

Steindachner (1915a) while describing Trichomycterus venulosus, omitted any mention on its pelvic-less condition, action repeated along the text of its more detailed redescription (Steindachner, 1915b). Nonetheless, the syntype specimen illustrated in this last work, clearly shows a fish lacking pelvic fins (Fig. 1A), calling the attention that this particular anatomical feature of this species would remain unnoticed by Eigenmann (1918) in his revision of the family, as well as by all subsequent authors. Diagnosis of Eremophilus relied in Eigenmann's revisionary work, exclusively upon a single character, which precisely consists in the absence of pelvic fins. This character remained for a long time as the only diagnostic feature defining Eremophilus, until Arratia (1990) offered two additional derived characters to diagnose the genus: lateral ethmoid with a sharp posteroventral process and liver with transverse portion and a long left lobe. The first putative autapomorphy was confirmed by us as exclusively occurring in E. mutisii within trichomycterids, from a comprehensive comparative evaluation of all currently recognized genera of Trichomycterinae, as well as representative genera and species of remaining trichomycterid subfamilies. However presence of the lateral ethmoid process in the syntypes of
T. venulosus could not be confirmed by radiographs, given that superimposition of several bony elements placed at different levels in the dorsoventral axis, conceal the limits and articulations of the bones forming the floor of neurocranium at the ethmoid region. Arratia (1998) later proposed an apomorphic condition of the head laterosensory system for E. mutisii, consisting in the absence of the nasal section of the supraorbital canal. However our examination of available specimens of E. mutisii did not confirm this observation, but revealed the consistent presence of a pair of anterior sensory pores ( 1 and s2), medially adjacent to anterior and posterior nares respectively, corresponding to the nasal section, which is posteriorly interrupted from the section enclosed by the frontal bone. This pattern constitutes a different apomorphic condition for trichomycterids (Fernández, 2006), being the plesiomorphic character state an uninterrupted supraorbital canal between nasal and frontal sections as documented for nematogenyids (Arratia \& Huaquin, 1995), and the basal trichomycterids of the subfamily Copionodontinae (Arratia, 1998; pers. obs.). Additionally in those trichomycterids with a continuous supraorbital canal, there are only two sensory pores in the snout region ( $\mathrm{s} 1$ and $\mathrm{s} 3$ ), thus representing the plesiomorphic pattern of supraorbital sensory pores for the family.

An additional apomorphic character present in E. mutisii, though not exclusively, is the high number of precaudal vertebrae (17-18 vertebrae). Nematogenids, and most basal trichomycterids (copionodontines and trichogenines), as well as most other trichomycterids, have lower counts of precaudal vertebrae, generally not exceeding from 10 vertebrae. Few exceptions are found in the very elongated forms of the subfamily Glanapteryginae (e.g., Glanapteryx anguilla Myers, 1927, with 47 vertebrae), but clearly this even higher vertebral count could represent a further derived character state.

Finally, regarding the conservation status of Trichomycterus venulosus proposed as possibly the second Colombian fish species extinct (Prada-Pedreros et al., 2006), the elucidation of its actual taxonomic status radically change this view. Eremophilus mutisii was described from the río Bogotá at salto de Tequendama and is distributed in the rivers draining to the río Magdalena basin on the altiplano Cundinoboyacense, between 2500$3100 \mathrm{~m}$ asl (Maldonado Ocampo et al., 2005; ÁlvarezLeón et al., 2012). The species has been successfully introduced in other drainage systems as Lago de Tota (río Orinoco basin) and Laguna de La Cocha (río Amazonas basin) (Álvarez-León et al., 2012). However, E. mutisii is currently categorized as vulnerable (VU B2b iii), and based on the field results obtained by Prada-Pedreros et al. (2006), it can be concluded at least that local populations from the Páramo de Cruz Verde are now extirpated. In fact, taking into account the original distribution of the species, we can assume that the two specimens that formed the basis of Steindachner's description of $T$. venulosus, were collected on the Magdalena versant of the Páramo. 
Comparative material. Copionodon pecten: Brazil: Bahia: MBUCV-V-32259, 5, 50.2-59.3 mm SL (1 CS, 52.9 mm SL), Município de Lençóis, tributary river of rio Paraguaçu, 12³4'00”S 41 22 '00"W. MHNLS 15887, 2, 39.0-41.8 mm SL (1 CS, 41.8 $\mathrm{mm} \mathrm{SL})$, Município de Lençóis, tributary river of rio Paraguaçu, ca. $3.5 \mathrm{~km}$ S from Lençóis. Eremophilus mutisii: Colombia: río Magdalena basin: Cundinamarca: MBUCV-V-29489, 1, 161.7 mm SL, río Tibitó, Zipaquirá. MPUJ 1599, 2, 193.9-196.6 mm SL (RX), Municipio de Chocontá, Embalse del Sisga, río Bogotá drainage. MPUJ 1963, 2, 142.2-142.8 mm SL (1 CS, $142.2 \mathrm{~mm}$ SL), Municipio Suesca, río Bogotá. MPUJ 2528, 2, 54.0-72.1 mm SL, Municipio Guatavita, embalse de Tominé, Vereda Chaleche, Club Náutico Refugio de Tominé, 0459'10.7'N 7349'09'”, $2622 \mathrm{~m}$ asl., Amazon River basin (introduced): Nariño: MBUCVV-32796, 1, 221.9 mm SL, Laguna de La Cocha, río Guamuéz drainage, tributary of río Putumayo. Trichomycterus alternatus: Brazil: FMNH 58082, holotype of Pygidium alternatum Eigenmann, 1918, 64.9 mm SL, rio Doce. FMNH 58083, paratypes of Pygidium alternatum, Eigenmann, 1918, 62, 29.1-59.0 mm SL, same locality as FMNH 58082. Trichomycterus arleoi: Venezuela: Río Yaracuy basin: Yaracuy: EBRG 10412, 47, 26.6-61.2 mm SL (2 CS, 54.5-58.9 mm SL), San Felipe, río Cocorotico, alto Jabiro. MBUCV-V-35627 (ex EBRG 10412), 9, 29.4-53.6 mm SL (1 CS, $58.9 \mathrm{~mm}$ SL). Trichomycterus banneaui: Colombia: Río Magdalena basin: Tolima: CZUT-IC 1270, 2, 35.2-36.9 mm SL (1 CS, $36.9 \mathrm{~mm} \mathrm{SL}$ ), Municipio Honda, quebrada Bernal, 05²12'13”N 7446'57'W. FMNH 56025, holotype of Pygidium banneaui Eigenmann, 1912, $36.9 \mathrm{~mm}$ SL, quebrada Bernal, near Honda. FMNH 56026, 20, 16.4-36.0 mm SL, same locality as FMNH 56025. FMNH 69815, paratypes of Pygidium banneaui Eigenmann, 1912, 34, 18.2-30.0 mm SL, same locality as FMNH 56025. Trichomycterus barbouri: Bolivia: FMNH 53946, paratypes of Pygidium barbouri Eigenmann, 1911, 5, 25.5-29.0 mm SL, upper río Beni, eastern Bolivia. MCZ 29313, holotype of Pygidium barbouri Eigenmann, 1911, 29.7 mm SL, same locality as FMNH 53946. MCZ 29314, paratypes of Pygidium barbouri Eigenmann, 1911, 23, 25.1-32.2 mm SL, same locality as MCZ 29313. Trichomycterus bogotensis: Colombia: Río Magdalena basin: Cundinamarca: FMNH 56030, holotype of Pygidium bogotense Eigenmann, 1912, $64.6 \mathrm{~mm}$ SL, Chapinero. FMNH 56031, paratypes of Pygidium bogotense Eigenmann, 1912, 128 (not measured), same locality as FMNH 56030. Boyacá: MPUJ 1953, 1, 38.1 mm SL, Municipio Cuítiva, quebrada Goyeneche, tributary of río Chicamocha, $2550 \mathrm{~m}$ a.s.1. Trichomycterus brasiliensis: Brazil: Minas Gerais: MBUCV-V-32257, 2, 56.0$109.9 \mathrm{~mm}$ SL (1 CS, $56.0 \mathrm{~mm} \mathrm{SL}$ ), stream tributary of córrego Mutuca, at right of entrance to Belo Horizonte-Nova Lima road (km 20), Nova Lima, rio das Velhas drainage, 1958'00"S 4352'00"W. Trichomycterus cachiraensis: Colombia: Río Magdalena basin: Norte de Santander: MBUCV-V-35384, paratypes of Trichomycterus cachiraensis Ardila Rodríguez, 2008, 3, 65.8-77.4 mm SL (1 CS, 74.9 mm SL), Municipio Cáchira, río Galvánes, upper tributary of río Cáchira, $07^{\circ} 44^{\prime} 47^{\prime} \mathrm{N}$ 7303'04”W, $2025 \mathrm{~m}$ asl. Trichomycterus caliensis: Colombia: Río Magdalena basin: Valle del Cauca: FMNH 56029, holotype of Pygidium caliense Eigenmann, 1912, 43.8 mm SL, Cali, río
Cauca drainage, $1009 \mathrm{~m}$ asl. Trichomycterus celsae: Venezuela: Río Orinoco basin: Bolívar: MBUCV-CT-1049, 1 CS, $53.0 \mathrm{~mm}$ SL, creek tributary of left margin of río Kukenán (headwaters), valley between tepuy Roraima and tepuy Kukenán, Gran Sabana, río Caroní drainage, $05^{\circ} 06$ '30"N 6049’48”W. Trichomycterus chapmani: Colombia: Río Magdalena basin: Quindío: CZUT-IC 1148, 1, $41.7 \mathrm{~mm}$ SL, creek in Finca Pasatiempo, río Cauca drainage. Quindío: FMNH 56027, holotype of Pygidium chapmani Eigenmann, 1912, 89.5 mm SL, Boquía, $1745 \mathrm{~m}$ asl, río Cauca drainage. FMNH 56028, paratypes of Pygidium chapmani Eigenmann, 1912, 10, 31.7-74.1 mm SL, same locality as FMNH 56027. FMNH 69813, 16, 17.5-45.4 mm SL, Boquía, río Quindío, río Cauca drainage. MBUCV-V-30945, 2, 46.4-64.4 mm SL (1 CS, $46.4 \mathrm{~mm}$ SL), río Quindío, Club de Tiro, Caza y Pesca, río Cauca drainage. MBUCV-V-30946, 2, 80.9-82.6 mm SL, same locality as MBUCV-V-30945. Valle del Cauca: CZUT-IC 60, 1, 87.8 mm SL, upper río Cauca drainage. MPUJ 1950, 2, 69.7-82.6 mm SL (1 CS, $69.7 \mathrm{~mm} \mathrm{SL}$ ), Municipio Florida, quebrada Las Cañas, Finca La Romana, río Cauca drainage. MPUJ 1951, 2 , 75.1-84.3 mm SL, collected with MPUJ 1950. Trichomycterus conradi: Guyana: Essequibo River basin: FMNH 53721, holotype of Pygidium conradi Eigenmann, 1912, 34.0 mm SL, Amatuk. Trichomycterus davisi: Brazil: Paraná: FMNH 54242, paratypes of Pygidium davisi Haseman, 1911, 9, mixed lot separated by W. Wosiacki containing 8 specimens of Trichomycterus davisi (20.8$43.3 \mathrm{~mm} \mathrm{SL}$ ) and 1 specimen of Trichomycterus sp. (138.7 mm SL), Serrinha, small creek flowing into Iguassu. FMNH 60309, holotype of Pygidium davisi Haseman, 1911, 41.6 mm SL, same locality as FMNH 54242. Trichomycterus dorsostriatus: Colombia: Río Orinoco basin: Meta: FMNH 58096, holotype of Pygidium dorsostriatum Eigenmann, 1918, $65.8 \mathrm{~mm}$ SL, Villavicencio. FMNH 58097, paratype of Pygidium dorsostriatum Eigenmann, 1918, 1, 17.9 mm SL, same locality as FMNH 58096. Trichomycterus emanueli: Venezuela: Lago de Maracaibo basin: Mérida: MBUCV-V-2157, 238, 32.8-191.9 (female) mm SL, río Escalante, bridge in the road El Vigía-San Cristóbal. MBUCV-V35616, 6, 116.9-178.7 mm SL, quebrada La Loma, tributary of río San Pedro, Santa Apolonia, $835 \mathrm{~m}$ asl. MCZ 37214, paratypes of Pygidium emanueli emanueli Schultz, 1944, 5, 78.7-118.8 mm $\mathrm{SL}$, río Chama at Estanques, $\mathrm{S}$ end of Lago de Maracaibo, 08³0'00”N 7140'00”W. Trichomycterus gorgona: Colombia: Cauca: ANSP 149946, holotype of Trichomycterus gorgona Fernández \& Schaefer, 2005, $64.3 \mathrm{~mm} \mathrm{SL}$, isla Gorgona, freshwater stream near NE end of island, Argosy Ecuador Expedition station 29, 02 $59^{\circ} 00^{\prime \prime} \mathrm{N} 78^{\circ} 11$ '30"W. Trichomycterus guianensis: Guyana: Essequibo River basin: FMNH 52676, holotype of Pygidium guianensis Eigenmann, 1909, 64.1 mm SL, Aruataima falls, upper Potaro River. Trichomycterus iheringi: Brazil: São Paulo: FMNH 58074, paratypes of Pygidium iheringi Eigenmann, 1918, 2, 127.2-132.7 m SL, Sapina. Trichomycterus immaculatus: Brazil: Minas Gerais: MCZ 8300, syntypes of Pygidium immaculatus Eigenmann \& Eigenmann, 1889, 5, 123.8$172.8 \mathrm{~mm}$ SL, rio Parahybuna at Juiz de Fora, 21\%47'00'S $43^{\circ} 23^{\prime} 00^{\prime}$ 'W. MCZ 8307, syntypes of Pygidium immaculatus Eigenmann \& Eigenmann, 1889, 9, 49.6-123.7 mm SL, Juiz de Fora and environs in the Paraiba valley. Trichomycterus knerii: 
Ecuador: Amazon River basin: NMW 43328, 1, syntype of Trichomycterus kneri Steindachner, 1882, $80.0 \mathrm{~mm}$ SL, Canelos, 01³5'S 7745’W. Trichomycterus latistriatus: Colombia: Río Magdalena basin: Santander: FMNH 58449, holotype of Pygidium latistriatum Eigenmann, 1918, 38.6 mm SL, quebrada Pinchote. Norte de Santander: MPUJ 1964, 2, 26.0-36.4 mm SL, Municipio Piratama, cerro Piratama, 08¹4'00"N 73¹5'00'W, 1540 m asl. Trichomycterus lewi: Venezuela: Río Orinoco basin: Bolívar: MBUCV-CT-1050, 1 CS, 62.0 mm SL, río Kukenán (headwaters), valley between tepuy Roraima and tepuy Kukenán, Gran Sabana, río Caroní drainage, $05^{\circ} 06^{\prime} 30^{\prime} \mathrm{N} 60^{\circ} 49^{\prime} 48^{\prime} \mathrm{W}$. Trichomycterus maracaiboensis: Venezuela: Lago de Maracaibo basin: Mérida: MBUCV-V-2178, 5, 39.0-63.8 mm SL, río Onia, tributary of río Escalante, ca. $8 \mathrm{~km}$ from bridge in the road El Vigía - San Cristobal. Zulia: MBUCV-V-18301, 4, 33.6-44.7 mm SL, río Palmar, in hacienda El Milagro, NW from Villa del Rosario, Sierra de Perijá piedmont. MCZ 37240, paratypes of Pygidium banneaui maracaiboensis Schultz, 1944, 3, 46.1-48.7 mm SL, río Machango, $20 \mathrm{~km}$ above bridge $\mathrm{S}$ of Lagunillas. Trichomycterus meridae: Venezuela: Lago de Maracaibo basin: Mérida: MBUCVV-32238, 3, 42.1-57.5 mm SL (1 CS, 54.8 mm SL), quebrada La Roncona, near from Chiguará, río Chama drainage, $1070 \mathrm{~m}$ asl. Trichomycterus mondolfi: Venezuela: Río Tuy basin: Miranda: MBUCV-V-3993, 37, 25.4-68.2 mm SL (3 CS, 51.8-58.8 mm $\mathrm{SL})$, quebrada Tusmare, near from El Hatillo, río Guaire drainage. MBUCV-V-21260, 3, 29.2-61.0 mm SL, río Palmira, Palmira. Trichomycterus motatanensis: Venezuela: Lago de Maracaibo basin: Zulia: MCZ 37282, paratype of Pygidium emanueli motatanensis Schultz, 1944, 1, 45.9 mm SL, río San Juan, near bridge S of Mene Grande, tributary of río Motatán, 0949'00'N 7056'00"W. Trichomycterus ocanaensis: Colombia: Lago de Maracaibo basin: Norte de Santander: MBUCV-V-35378 (ex CAR 386), paratypes of Trichomycterus ocanaensis Ardila Rodríguez 2012, 5, 28.6-60.0 mm SL (1CS, $51.0 \mathrm{~mm} \mathrm{SL),}$ Municipio Ocaña, río Tejo, tributary of río Algodonal, $08^{\circ} 14^{\prime} 15^{\prime \prime} \mathrm{N}$ 7302'26" W, $1202 \mathrm{~m}$ asl, upper basin of río Catatumbo. Trichomycterus oroyae: Peru: Junin: MCZ 3955, syntypes of Pygidium oroyae Eigenmann \& Eigenmann, 1889, 7, 99.1-126.2 mm SL, río de Oroya at Pochochacra, near La Oroya, 3962-4145 $\mathrm{m}$ asl. Trichomycterus paolencis: Brazil: São Paulo: FMNH 58085, holotype of Pygidium paolence Eigenmann, 1918, 58.3 mm SL, Alto da Serra. FMNH 58575, 1 specimen of Trichomycterus sp. designated as paratype of Pygidium paolence, $54.3 \mathrm{~mm}$ SL, rio Paranahyba bridge. Trichomycterus pardus: Peru: La Libertad: ANSP 22004, holotype of Trichomycterus pardus Cope, 1874, 58.6 mm SL, Jequetepeque. Trichomycterus piurae: Peru: Piura: FMNH 58672, paratypes of Pygidium punctulatum piurae Eigenmann, 1922, 3, 53.0-99.1 mm SL, río Puira at Puira. FMNH 77904, paratypes of Pygidium punctulatum piurae Eigenmann, 1922, 5, 55.6-66.7 mm SL, same locality as FMNH 58672. Trichomycterus pradensis: Brazil: Bahia: ANSP 180783, paratypes of Trichomycterus pradensis Sarmento-Soares, MartinsPinheiro, Aranda \& Chamon, 2005, 3, 43.7-55.7 mm SL, Itanhém, córrego da Água Preta, on road Jeribá-Itanhém, near Santa Rita village, upper rio Itanhém basin, 16059'41'S 40²3'52"W. Trichomycterus reinhardti: Brazil: Minas Gerais: FMNH 58081, holotype of Pygidium reinhardti Eigenmann, 1918, 53.6 mm SL, Burmier, rio Itabira, tributary of rio das Velhas. Minas Gerais: MBUCV-V-32256, 2, 38.2-44.7 mm SL (1 CS, 38.2 mm SL), stream tributary of rio das Pombas, km 719 of road BR-040,

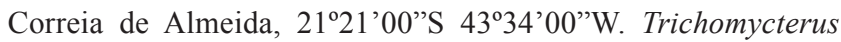
retropinnis: Colombia: Huila: MBUCV-V-32797, 4, 43.0-65.0 mm SL (1 CS, $61.4 \mathrm{~mm}$ SL), Municipio San Agustín, creek between vereda Quebradillas and vereda Arauca. Trichomycterus romeroi: Colombia: Río Magdalena basin: Tolima: ANSP 69331, holotype of Pygidium romeroi Fowler, 1941, $54.4 \mathrm{~mm}$ SL, Honda. ANSP 69332, mixed lot containing 3 paratypes of Pygidium romeroi Fowler, 1941, 29.7-47.0 mm SL, plus 1 specimen of Trichomycterus sp., $30.5 \mathrm{~mm} \mathrm{SL}$, (1 CS: type status of this specimen is questionable, according to note from Sabaj-Pérez of 21 Apr 2005, accompanying respective lot), same locality as ANSP 69331. Trichomycterus ruitoquensis: Colombia: Río Magdalena basin: Santander: IAvH-P 4340, 5, 40.1-52.2 mm SL (1 CS, 39.9 mm SL), Municipio Rionegro, río Santacruz in vereda San Jorge, río Lebrija drainage, $07^{\circ} 15^{\prime} 51.84^{\prime}{ }^{\circ} 7^{\circ} 08^{\prime} 58.92^{\prime \prime} \mathrm{W}$, $590 \mathrm{~m}$ asl. Trichomycterus santaeritae: Brazil: FMNH 58577, holotype of Pygidium santaeritae Eigenmann, 1918, 24.0 mm SL, Santa Rita, rio Preto. Trichomycterus sketi: Colombia: Río Magdalena basin: Santander: ANSP 189652, paratype of Trichomycterus sketi Castellanos-Morales, 2011, 1, 60.8 mm SL, Municipio La Paz, vereda Casas Blancas, cueva del Indio, upper río Opón basin, 0605021”N 7305’18”W, $2157 \mathrm{~m}$ asl. Trichomycterus spelaeus: Venezuela: Lago de Maracaibo basin: Zulia: MBUCV-V-29602, holotype of Trichomycterus spelaeus DoNascimiento, Villarreal \& Provenzano, 2001, 54.1 mm SL, cueva Punto Fijo, caserío Punto Fijo, $7.5 \mathrm{~km} \mathrm{~N}$ from cerro Yolanda, río Guasare drainage, $10^{\circ} 57^{\prime} 10^{\prime} \mathrm{N} 72^{\circ} 28^{\prime} 06^{\prime \prime} \mathrm{W}, 590 \mathrm{~m}$ asl. MBUCV-V-29603, paratypes of Trichomycterus spelaeus DoNascimiento, Villarreal \& Provenzano, 2001, 2, 29.4-34.6 mm SL (1 CS, $34.6 \mathrm{~mm} \mathrm{SL}$ ), collected with the holotype. Trichomycterus stellatus: Colombia: Cundinamarca: FMNH 58101, holotype of Pygidium stellatum Eigenmann, 1918, 65.8 mm SL, quebrada Sargento, southern Colombia. FMNH 58102, paratypes of Pygidium stellatum Eigenmann, 1918, 3, 54.5-72.7 mm SL, same locality as FMNH 58101. Tolima: FMNH 58100, paratypes of Pygidium stellatum Eigenmann, 1918, 3 37.8-75.5 mm SL, quebrada Guamal, southern Colombia. FMNH 58103, paratypes of Pygidium stellatum Eigenmann, 1918, 3, 28.3-46.7 mm SL, quebrada Guadual. FMNH 58104, paratypes of Pygidium stellatum Eigenmann, 1918, 9, 24.6-35.4 mm SL, río Guaduas. Trichomycterus striatus: Colombia: Río Magdalena basin: Huila: CZUT-IC 968, 2, 74.5-79.3 mm SL (1 CS, 79.3 mm SL), Municipio Aipe, río Patá, at Inspección de Policía de El Patá, 03²6'57’N 75¹1'26”W. Tolima: CZUT-IC 480, 2, 52.8-66.5 mm SL (1 CS, $52.8 \mathrm{~mm} \mathrm{SL}$ ), Municipio Coello, $50 \mathrm{~m}$ downriver from feeder of irrigation district USOCOELLO, Inspección de Policía de

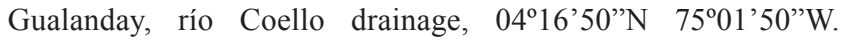
Panama: Chiriquí: FMNH 59195, paratype of Pygidium septentrionale Behre, 1928, 1, 77.6 mm SL, quebrada Sombrero into río Chiriquí del Tire. FMNH 59522, holotype of Pygidium septentrionale Behre, 1928, 89.7 mm SL, quebrada Salao into río Chiriquí del Tire. Darién: FMNH 7579, holotype of Pygidium 
striatum Meek \& Hildebrand, 1913, 71.9 mm SL, río Cana, Cana. FMNH 26660, paratype of Pygidium striatum Meek \& Hildebrand, 1913, 1, $53.6 \mathrm{~mm}$ SL, same locality as FMNH 7579. FMNH 26661, paratype of Pygidium striatum Meek \& Hildebrand, 1913, 1, $65.7 \mathrm{~mm}$ SL, same locality as FMNH 7579. FMNH 26662, paratype of Pygidium striatum Meek \& Hildebrand, 1913, 1, 43.6 mm SL, same locality as FMNH 7579. FMNH 55233, paratype of Pygidium striatum Meek \& Hildebrand, 1913, 1, 53.6 mm SL, same locality as FMNH 7579. Trichomycterus taeniops: Peru: Río Amazonas basin: Junin: ANSP 71638, holotype of Pygidium tenue Fowler, 1945, $82.1 \mathrm{~mm}$ SL, Acobamba, near Tarma, río Ucayale drainage, $2000 \mathrm{~m}$ asl. Trichomycterus transandianums: Colombia: Río Magdalena basin: Huila: MPUJ 1962, 2, 51.3$52.2 \mathrm{~mm} \mathrm{SL}$, Municipio Neiva, creek in vereda Tamarindo, 0304'04”N 75²2'38”W, $680 \mathrm{~m}$ asl. Tolima: CZUT-IC 475, 1, $67.3 \mathrm{~mm} \mathrm{SL}$, Municipio Ibagué, lower quebrada Cay, $50 \mathrm{~m}$ downriver from aqueduct of Ibagué, río Coello drainage, 04'27'59'N 75'15'48'W. NMW 44475, 7, syntypes of Pygidium taenia transandianum Steindachner, 1915, 23.0-53.0 mm SL, mountain stream in Cañon del Gallo, a right tributary valley of río Combeima, Central Cordillera, Colombia, $1800 \mathrm{~m}$ asl, 04¹9'N 7509'W. Trichomycterus triguttatus: Brazil: São Paulo: FMNH 58670, holotype of Pygidium triguttatum Eigenmann, 1918, 30.4 mm SL, Jacarehy. FMNH 58671, paratypes of Pygidium triguttatum Eigenmann, 1918, 3, 21.5-28.9 mm SL, same locality as FMNH 58670. Trichomycterus uisae: Colombia: Río Magdalena basin: Santander: ANSP 187498, paratype of Trichomycterus uisae Castellanos-Morales, 2008, 1, 43.4 mm SL, Municipio de Los Santos, cueva El Misterio, Acuarela road 3.5 $\mathrm{km}$, vereda Mesa de Los Santos, upper río Sogamoso drainage, 06 50 '21"N 7305'18'W, $1600 \mathrm{~m}$ asl. Trichomycterus vermiculatus: Brazil: Minas Gerais: FMNH 58077, holotype of Pygidium vermiculatum Eigenmann, 1918, 113.4 mm SL, Juiz de Fora. Trichomycterus weirauchi: Peru: Río Amazonas basin: Junin: ANSP 71639, holotype of Pygidium weirauchi Fowler, 1945, 41.8 mm SL, Acobamba, near Tarma, río Ucayali drainage, $2200 \mathrm{~m}$ asl. ANSP 71640, paratype of Pygidium weirauchi Fowler, 1945, 1, $37.2 \mathrm{~mm}$ SL, same locality as ANSP 71639. Trichomycterus zonatus: Brazil: São Paulo: FMNH 58572, paratype of Pygidium zonatum Eigenmann, 1918, 1, $50.8 \mathrm{~mm} \mathrm{SL}$, Cubatao. FMNH 58573, holotype of Pygidium zonatum Eigenmann, 1918, 53.0 mm SL, Água Quente. FMNH 58574, paratypes of Pygidium zonatum Eigenmann, 1918, 2, 41.7-46.5 mm SL, same locality as FMNH 58573. Trichomycterus sp. A (Páramo de Cruz Verde): Colombia: Río Orinoco basin: Cundinamarca: MBUCV-V-35652, 2, 86.7-88.8 mm SL (MBUCVCT-1047, 1 CS, 86.7 mm SL), Ubaque, vereda Pueblo Nuevo, quebrada El Charco, tributary of quebrada Santa Bárbara, río El Palmar system, 0431'10.3”N 7358'44.6”W, $2700 \mathrm{~m}$ asl. MBUCV-CT-1053, 3 CS, specimens 2 \& 6 completely dissarticulated: 105.7-123.9 mm SL, specimen 5 entire: 106.8 mm SL, same locality as MBUCV-V-35652. MPUJ 2482, 6, 81.1$120.5 \mathrm{~mm}$ SL (RX), same locality as MBUCV-V-35652. MPUJ 2491, 2, 74.2-77.1 mm SL (RX), same locality as MBUCV-V35652. MPUJ 4191, $143.5 \mathrm{~mm}$ SL (RX), same locality as MBUCV-V-35652.

\section{Acknowledgments}

Special thanks are due to Ernst Mikschi (NMW) for loaning and allowing the examination of the syntypes of Pygidium venulosum. We kindly thank Gudrun Schulze from the Zoological Museum Hamburg for taking the x-ray plates. We are grateful to anonymous reviewers for valuable suggestions and corrections.

\section{Literature Cited}

Álvarez-León, R., A. Rodríguez-Forero, J. A. González-Acosta, R. Rosado-Puccini, S. Hernández Barrero, M. ValderramaBarco, G. A. Pinilla, P. Lehmann A., J. E. Forero-Useche, S. Prada-Pedreros, C. L. DoNascimiento \& J. GuerreroKommritz. 2012. Eremophilus mutisii Humboldt 1805. Pp. 114-117. In: Mojica, J. I., J. S. Usma, R. Álvarez-León \& C. A. Lasso (Eds.). Libro rojo de peces dulceacuícolas de Colombia 2012. Instituto de Investigación de Recursos Biológicos Alexander von Humboldt, Instituto de Ciencias Naturales de la Universidad Nacional de Colombia, WWF Colombia \& Universidad de Manizales, Bogotá, D.C., Colombia.

Arratia, G. 1990. The South American Trichomycterinae (Teleostei: Siluriformes), a problematic group. Pp. 395-403. In: Peters, G. \& R. Hutterer (Eds.). Vertebrates in the tropics: Proceedings of the International Symposium on Vertebrate Biogeography and Systematics in the Tropics, Bonn, June 5-8, 1989, Bonn, Alexander Koenig Zoological Research Institute and Zoological Museum.

Arratia, G. 1998. Silvinichthys, a new genus of trichomycterid catfishes from the Argentinian Andes, with redescription of Trichomycterus nigricans. Ichthyological Exploration of Freshwaters, 9: 347-370.

Arratia, G. \& L. Huaquin. 1995. Morphology of the lateral line system and of the skin of diplomystid and certain primitive loricarioid catfishes and systematic and ecological considerations. Bonner Zoologische Monographien, 36: $1-110$.

Arratia, G. \& S. Menu Marque. 1984. New catfishes of the genus Trichomycterus from the high Andes of South America (Pisces, Siluriformes) with remarks on distribution and ecology. Zoologische Jahrbücher, Systematik, 111: 493-520.

Barbosa, M. A. \& W. J. E. M. Costa. 2003. Validade, relações filogenéticas e redescrição de Eremophilus candidus Ribeiro, 1949 (Teleostei, Siluriformes, Trichomycteridae). Arquivos do Museu Nacional, 61: 179-188.

Dahl, G. 1971. Los peces del norte de Colombia. Ministerio de Agricultura, Instituto de Desarrollo de los Recursos Naturales Renovables, Bogotá, D. E., Inderena.

Eigenmann, C. H. 1918. The Pygidiidae, a subfamily of South American catfishes. Memoirs of the Carnegie Museum, 7: 259-398.

Fernández, L. A. 2006. Two new patterns of the supraorbital canal in trichomycterids (Siluriformes: Trichomycteridae). Acta Zoológica Lilloana, 50: 115-117.

Fernández, L. \& K. Osinaga. 2006. A new Trichomycterus (Siluriformes: Trichomycteridae) from Aguarague National Park of the Bolivian preandean region, with comments on the relationships within the genus. Environmental Biology of Fishes, 75: 385-393. 
Fernández, L., E. A. Sanabria \& L. B. Quiroga. 2013. Silvinichthys gualcamayo, a new species of catfish from the central Andes of Argentina (Siluriformes: Trichomycteridae). Ichthyological Exploration of Freshwaters, 23: 367-373.

Fernández, L. \& R. P. Vari. 2000. New Species of Trichomycterus (Teleostei: Siluriformes: Trichomycteridae) lacking a pelvic fin and girdle from the Andes of Argentina. Copeia, 2000: 990996.

Fernández, L. \& R. P. Vari. 2012. New Species of Trichomycterus (Teleostei: Siluriformes) from the Andean Cordillera of Argentina and the Second Record of the Genus in Thermal Waters. Copeia, 2012: 631-636.

Ferraris, C. J., Jr. 2007. Checklist of catfishes, recent and fossil (Osteichthyes: Siluriformes), and catalogue of siluriform primary types. Zootaxa, 1418: 1-628.

Lundberg, J. G. \& J. N. Baskin. 1969. The caudal skeleton of the catfishes, Order Siluriformes. American Museum Novitates, 2398: 1-49.

Maldonado-Ocampo, J. A., A. Ortega-Lara, J. S. Usma Oviedo, G. Galvis Vergara, F. A. Villa-Navarro, L. Vásquez Gamboa, S. Prada-Pedreros \& C. A. Rodríguez. 2005. Peces de los Andes de Colombia: guía de campo. Instituto de Investigación de Recursos Biológicos Alexander von Humboldt, Bogotá, Colombia.

de Pinna, M. C. C. 1989. A new sarcoglanidine catfish, phylogeny of its subfamily, and an appraisal of the phyletic status of the Trichomycterinae (Teleostei, Trichomycteridae). American Museum Novitates, 2950: 1-25. de Pinna, M. C. C. \& W. B. Wosiacki. 2003. Family Trichomycteridae (pencil or parasitic catfishes). Pp. 270-290. In: Reis, R. E., S. O. Kullander \& C. J. Ferraris Jr. (Eds.). Check list of the freshwater fishes of South and Central America. Porto Alegre, Edipucrs.

Prada-Pedreros, S., C. A. Rivera-Rondón \& J. Guerrero-Kommritz. 2006. Trichomycterus venulosus (Steindachner, 1915): posible extint species from the Páramo de Cruz Verde (Cundinamarca, Colombia). Biota Colombiana, 7: 165-168.

Steindachner, F. 1915a. Vorlaüfigen Bericht über einige neue Süsswasserfische aus Südamerika. Anzeiger der Kaiserlichen Akademie der Wissenschaften, MathematischNaturwissenschaftlichen Classe, 52: 199-202.

Steindachner, F. 1915b. Beiträge zur Kenntniss der Flussfische Südamerikas, V. Denkschriften der MathematischNaturwissenschaftlichen Classe der Kaiserlichen Akademie der Wissenschaften in Wien, 93: 15-106.

Taylor, W. R. \& G. C. Van Dyke. 1985. Revised procedures for staining and clearing small fishes and other vertebrates for bone and cartilage study. Cybium, 9: 107-119.

Wosiacki, W. B. \& O. T. Oyakawa. 2005. Two new species of the catfish genus Trichomycterus (Siluriformes: Trichomycteridae) from the rio Ribeira de Iguape Basin, Southeastern Brazil. Neotropical Ichthyology, 3: 465-472.

Submitted December 31, 2013 Accepted June 11, 2014 by Francisco Langeani

Published December 27, 2014 
